\title{
PERANCANGAN PENGATURAN SINYAL/RAMBU PADA STASIUN KERETA API BERSKALA KECIL BERBASIS PERSONAL KOMPUTER
}

\author{
Oleh \\ Ketut Udy Ariawan \\ Jurusan Teknik Elektronika, FTK, Undiksha
}

\begin{abstract}
ABSTRAK
Pada umumnya pengaturan sinyal/rambu pada stasiun kereta api berskala kecil masih menggunakan sistem manual (dijalankan oleh operator/manusia) yaitu menggunakan sebuah rantai penarik untuk menggerakkan palang sebagai sinyal/rambu bagi kereta api yang masuk ke stasiun. Berbeda halnya dengan sistem pengaturan sinyal/rambu pada stasiun kereta api berskala besar yang sudah lebih canggih yang serba otomatis, tetapi sangat disayangkan sekali biaya yang dibutuhkan untuk membuat sistem tersebut sangat mahal. Data ini didapatkan melalui studi visual dan studi perbandingan yang dilakukan oleh penulis di Stasiun Kereta Api Bandung, Jawa Barat (Stasiun Hall) dan Stasiun Kereta Api Kiaracondong Bandung, Jawa Barat.

Dengan melihat permasalahan tersebut diatas maka solusi yang diambil adalah dengan membuat suatu perancangan alat pengatur sinyal/rambu kereta api yang berbasis personal komputer. Adapun alat yang digunakan dalam perancangan tersebut yaitu PPI 8255 sebagai antarmuka penghubung antara rangkaian elektronika dan komputer, motor DC untuk menggerakkan palang, seven segment untuk memberi tanda pada kereta api yang masuk agar pindah jalur atau tetap pada jalur, sensor untuk mendeteksi kedatangan kereta api yang masuk ke stasiun, serta lampu untuk memberi tanda pada kereta api bisa masuk ke stasiun atau tidak. Selain itu, penulis juga membuat perangkat lunak dengan menggunakan bahasa pemrograman Borland Delphi 5.0 untuk menjalankan aplikasi perancangan alat tersebut.
\end{abstract}

Kata-kata kunci : motor DC, seven segment, sensor infra merah, interface PPI 8255

\begin{abstract}
In general, setting signals / signs at small railway stations are still using manual system (run by the operator / human) is to use a towing chain to move the bar as a signal / signs for the train that goes to the station. Unlike the system of setting the signal / signs on large-scale railway stations are already more advanced automated, but unfortunately all costs required to make the system very expensive. Data was obtained through visual studies and comparative studies conducted by the authors at the Railway Station Bandung, West Java (Station Hall) and Railway Station Kiaracondong Bandung, West Java.

By looking at the problems described above, the solution adopted by the authors is to create a design of signal control devices / railroad signs based personal
\end{abstract}


computers. The tools used in the design of the PPI 8255 as the liaison interface between electronic circuits and computers, the DC motor to move the bar, seven segment put a mark on the train that goes to the moving point, or remain on track, the sensor for detecting the arrival of the incoming train to the station, as well as lights to signal the train can enter the station or not. In addition, the authors also make the software using Borland Delphi 5.0 programming language to run the application design tool.

Key words: DC motors, seven segment, infrared sensors, interface PPI 8255

\section{PENDAHULUAN}

Sarana transportasi pada masa sekarang ini merupakan suatu kebutuhan yang sangat penting bagi kehidupan manusia dalam kesehariannya. Sarana transportasi yang sering digunakan oleh manusia didalam melakukan aktivitas maupun melakukan interaksi dengan lingkungannya adalah dengan menggunakan alat transportasi darat, perairan (sungai, danau, laut), dan udara. Keinginan manusia dalam berinteraksi dengan menggunakan jasa transportasi darat adalah untuk lebih menghemat waktu dan menyebarkan informasi secara cepat. Banyak layanan yang ditawarkan untuk memenuhi kebutuhan tersebut antara lain mobil, sepeda motor, dan kereta api.

Kereta api merupakan salah satu alat transportasi darat yang banyak digunakan masyarakat terutama di Pulau Jawa. Dari tahun ke tahun kebutuhan masyarakat terhadap kereta api semakin meningkat, hal ini menyebabkan pelayanan jasa kereta api membutuhkan suatu pengaturan yang lebih komplek terutama pada stasiun-stasiun kereta api berskala kecil, mengingat pengaturan sinyal/rambu pada stasiun tersebut masih menggunakan sistem manual. Oleh karena tingginya kecepatan kereta api, yaitu mencapai $120 \mathrm{~km} / \mathrm{jam}$ atau lebih, maka keamanan perjalanannya harus lebih dijamin, terlebih lagi mengingat bahwa kereta api mengangkut secara besar-besaran baik manusia maupun barang. Suatu kecelakaan kereta api dalam perjalanannya dapat membawa korban berpuluh-puluh orang, sejumlah besar barang-barang terganggu pengangkutannya. Lagipula kerusakan rolling stock maupun jalan baja dapat mengakibatkan terhalangnya jalan, sehingga pengangkutan diatasnya terhenti untuk sementara waktu. Akibatnya tidak hanya 
kerugian bagi perusahaan angkutannya, akan tetapi dapat pula berpengaruh besar pada peredaran barang dan ekonomi negara. Kejadian itu harus dapat dihindari dan harus senantiasa diusahakan supaya kereta api berjalan dengan kecepatan yang telah ditentukan tanpa mendapat rintangan. Untuk maksud ini, disamping baiknya kondisi jalan, harus pula dijamin terhindarnya bahaya tumbukan dengan kereta api lainnya dengan mengatur sinyal/rambu pada stasiun kereta api.

Oleh karena itu, perlu diciptakan suatu alat yang bisa mengendalikan sinyal/rambu dengan menggunakan sistem komputerisasi. Alat tersebut berupa interface atau antarmuka dari sebuah komputer ke pengendali/pengontrol sinyal. Untuk di Indonesia alat semacam ini yang penulis ketahui hanya terdapat di stasiun berskala besar seperti Stasiun Gambir (Jakarta), Stasiun Hall (Bandung) dan stasiunstasiun berskala besar lainnya. Untuk itu perlu diciptakan suatu interface untuk simulasi tersebut dengan biaya yang tidak terlalu mahal dan terjangkau sehingga bisa digunakan di seluruh stasiun kereta api berskala kecil yang ada di Indonesia.

Dalam salah satu aplikasinya interface yang akan dirancang memiliki kegunaan khusus, bagaimana suatu sinyal/rambudapat dikontrol oleh suatu komputer dengan membuat interface terlebih dahulu.

\section{METODE}

Metode penelitian yang digunakan adalah metode penelitian tindakan yaitu penelitian dilaksanakan melalui tahap-tahap yang bertujuan untuk mencari dan membuat pemecahan masalah yang ada.

Studi pendahuluan penulisan, menggunakan studi kelayakan terhadap kelayakan sistem yang akan dibuat. Dimana tahap ini merupakan pondasi dalam memperdalam dan menjelaskan pemahaman terhadap masalah yang dihadapi. Dengan demikian diharapkan :

a. Dapat memahami dan mencari teori - teori yang diperlukan sebagai landasan. Dalam hal ini teori - teori yang digunakan adalah teori pembahasan unit personal komputer, paralel port, PPI 8255, pembanding alamat, analog digital 
converter, penguat operasional, optocoupler, motor - motor listrik, seven segment, komponen - komponen elektronik, dan bahasa pemrograman Borland Delphi 5.0 dan Assembler.

b. Dapat menentukan bagaimana cara teknik perancangan yang akan dibuat berdasarkan studi pendahuluan dari penelitian ini maka teknik perancangan yang akan dibuat dibagi dalam perancangan hardware meliputi perancangan rangkaian PPI 8255, sensor, seven segment dan motor sebagai mekanik untuk simulasi gerak.

c. Alat yang dirancang benar - benar dapat dibuat sesuai dengan keinginan. Perancangan sistem yang dibuat untuk alat pengatur sinyal/rambu kereta api ini merupakan pengembangan teknologi khususnya dari penggunaan PPI 8255 yang dapat dihubungkan dengan perangkat lainnya sebagai media masukan dan keluaran I/O.

Penelaahan pustaka, merupakan pengkajian dan pendalaman data yang berhubungan dengan kontruksi hardware dan software yang sebagian besar diambil dari buku - buku referensi, referensi electronic book, hand book of modern sensor dan buku - buku tentang motor listrik serta seven segment.

Analisa data, merupakan tahapan dimana tahapan ini untuk mengetahui dan memahami sistem yang akan dibuat, serta pengumpulan data yang diperlukan untuk pelaksanaan perancangan perangkat keras dan perangkat lunak. Dalam perancangan, dibagi dua tahap perancangan diantaranya yaitu perancangan terhadap perangkat keras dan perancangan perangkat lunak. Kedua perancangan itu dirancang secara sistematis, dianalisa, didesain, pengkodean, uji coba dan pemeliharaan.

Tahap selanjutnya adalah melakukan uji coba yang dibagi kedalam dua pengujian yaitu pengujian pada perangkat lunak, yaitu meliputi :

a. Uji coba dalam rangkaian, yang bertujuan untuk mencari kesalahan.

b. Uji coba benda, yang bertujuan untuk mencari kesalahan sebanyak mungkin yang akan terjadi pada sistem.

c. Uji coba berhasil, yang bertujuan menemukan kesalahan yang sebelumnya tidak terduga. 
Setelah pengujian perangkat keras dan perangkat lunak, selanjutnya adalah penggabungan perangkat keras dan perangkat lunak. Langkah ini bertujuan untuk menyempurnakan sistem yang telah dirancang dan sesuai dengan yang diharapkan. mengevaluasi kembali terhadap semua tahap penelitian yang dilakukan dan menganalisis hasil yang dicapai, yang menjadi sasaran dalam penelitian ini. Tahap ini diharapkan akan lebih memudahkan didalam penarikan kesimpulan.

Setelah semua tahap dalam penelitian telah selesai dilakukan, maka tahap selanjutnya adalah menarik kesimpulan dari semua hasil pembahasan yang telah dilakukan. Sebagai dokumentasi dari penelitian yang telah dilakukan, maka tahap paling akhir yang perlu dilakukan adalah menuliskan laporan dari awal hingga akhir dalam penelitian sesuai dengan aturan yang berlaku.

\section{HASIL DAN PEMBAHASAN}

Komponen dari sistem penggerak palang sinyal/rambu terdiri atas komputer sebagai antarmuka alat/sensor dan mekanik penggerak palang sinyal/rambu. Sistem dibagi menjadi dua sub sistem yang lebih kecil, dimana sub sistem tersebut merepresentasikan modul-modul yang terpisah dari keseluruhan sistem. Sub sistem tersebut adalah :

1. Sub Sistem I $\rightarrow$ Komputer

2. Sub Sistem II $\rightarrow$ Sensor, Lampu, Seven Segment dan Mekanik

Sub Sistem I: Komputer disebut juga pengendali, merupakan tempat kerja dari operator yang berbentuk sebuah PC.
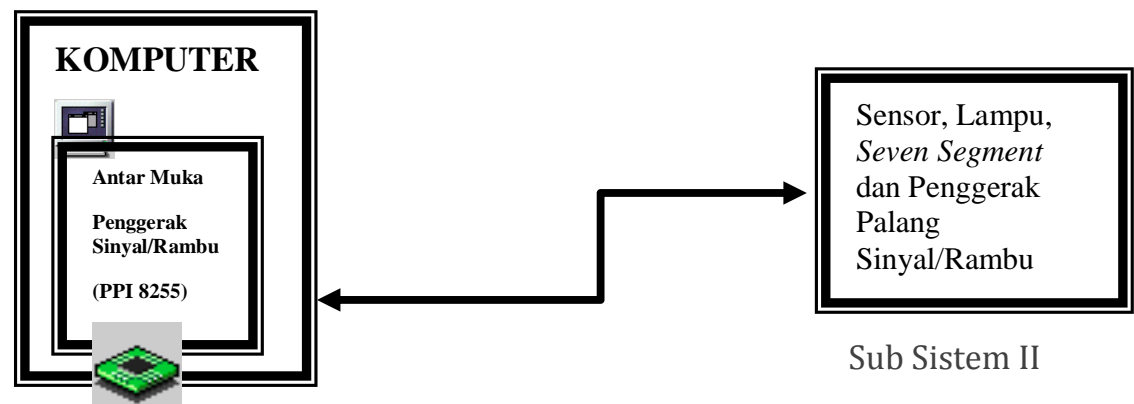

Sub Sistem II

Sub Sistem I

Gambar 1. Blok Diagram Sistem Penggerak Palang Sinyal/Rambu 
Sub Sistem II: Sensor penggerak palang sinyal/rambu menggunakan perubahan level tegangan akibat dari perubahan tegangan dari penerima sensor infra merah, penggerak sinyal/rambu digerakkan oleh mekanik, kemudian nilai tegangan dari resistor tersebut dikonversikan menggunakan CMOS MC14050 yang mana disini disebut sebagai pengubah tegangan. Desain blok dari sensor tersebut seperti pada gambar di bawah ini :

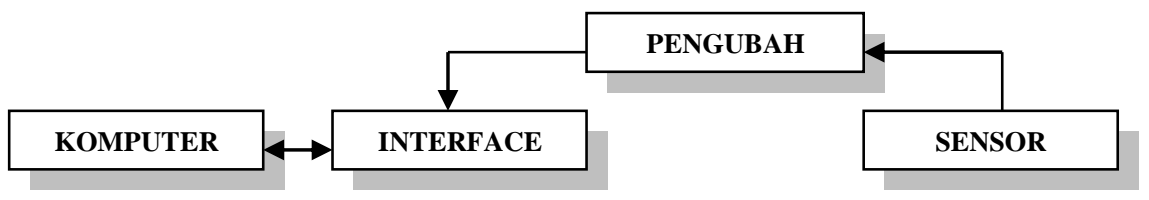

Gambar 2. Blok Diagram Sensor Penggerak Palang Sinyal/Rambu

Untuk mempermudah dalam perakitan dan pemahaman cara kerja dari rangkaian, maka perancangan dibuat berdasarkan per blok, dimana tiap blok mempunyai fungsi dan kerja tertentu, dimana blok rangkaian yang satu dengan yang lain saling berhubungan dan saling mendukung hingga terbentuk suatu rangkaian yang mempunyai satu fungsi dan kerja khusus. Diagram blok selengkapnya ditampilkan pada gambar sebagai berikut :

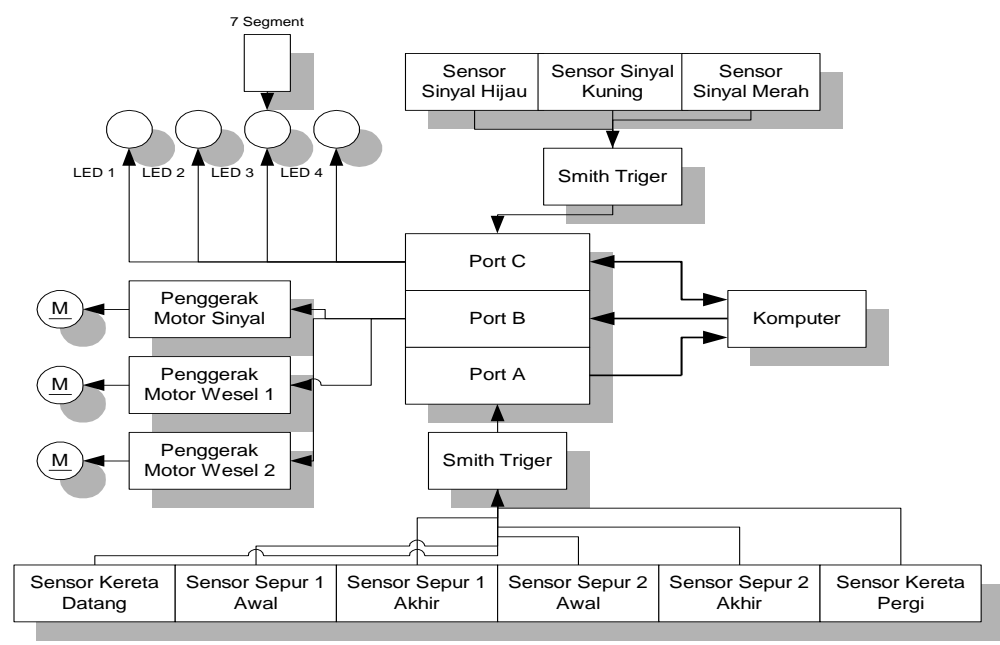

Gambar 3. Blok Diagram Keseluruhan 
Sensor akan mendeteksi datangnya kereta, kemudian mendeteksi status keberadaan kereta yang lain yang sudah ada di stasiun. Data dari sensor akan dirubah menjadi bentuk digital dan digunakan sebagai masukan ke komputer untuk menggerakkan motor DC serta menyalakan lampu dan seven segment sebagai bentuk pengatur sinyal/rambu bagi kereta api yang masuk ke stasiun. Apabila semuanya lancar maka kereta tersebut akan diperbolehkan untuk memasuki kawasan stasiun.

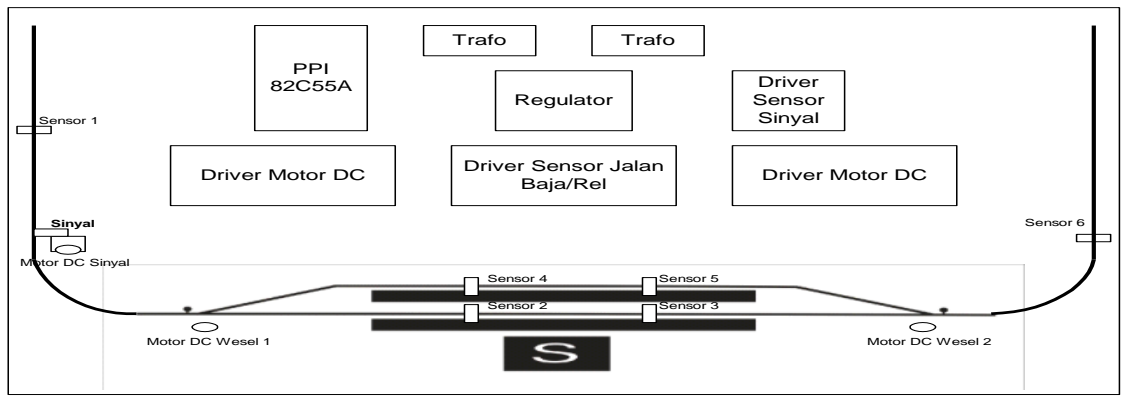

Gambar 4. Mekanik Keseluruhan Pengendali Sinyal/Rambu

\subsection{Hasil Pengujian dan Analisa PPI 8255}

Tabel 1. Hasil Pengujian PPI 8255

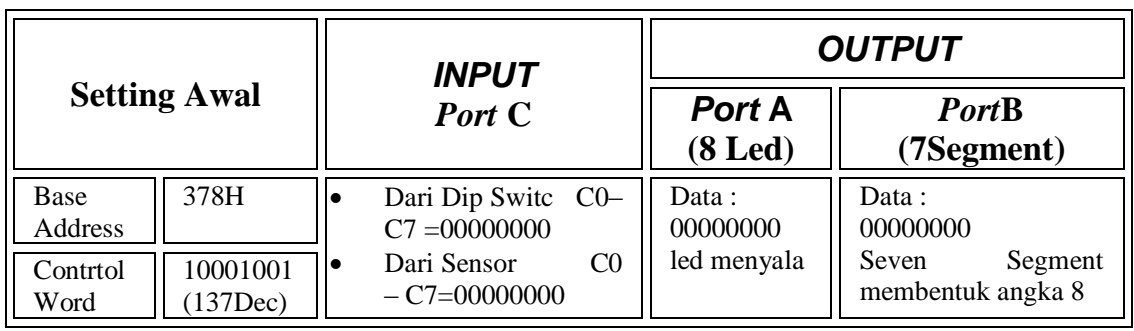

Setting control word 137Dec menyatakan bahwa PPI 8255 port A dan port B diatur sebagai keluaran dan port $\mathrm{C}$ sebagai masukan. Sebagai masukan yaitu dip switch dan sensor, jika dip switch berada pada posisi ON maka akan ditampilkan di program untuk C0-C7 yaitu 00000000 dan jika sensor berada pada level minimum akan ditampilkan data 11111111, sedangkan port A dan B diuji dengan memberikan data 00000000 maka 8 led maupun seven segment akan menyala. 


\subsection{Hasil Pengujian dan Analisa Catu Daya}

Tabel 2. Hasil Pengujian Catu Daya

\begin{tabular}{|c|c||c|c|}
\hline Pengukuran & $\begin{array}{c}\text { Vout 12VDC } \\
\text { (V) }\end{array}$ & $\begin{array}{c}\text { Vout 5 VDC } \\
\text { (V) }\end{array}$ & $\begin{array}{c}\text { Vout -12VDC } \\
\text { (V) }\end{array}$ \\
\hline \hline 1 & 11.90 & 5.01 & -11.90 \\
\hline 2 & 11.92 & 5.04 & -11.92 \\
\hline 3 & 11.93 & 5.03 & -11.93 \\
\hline 4 & 11.93 & 5.03 & -11.93 \\
\hline 5 & 11.95 & 5.02 & -11.95 \\
\hline
\end{tabular}

Tegangan keluaran dari rangkaian catu daya terlihat sudah sesuai dengan perancangan yaitu sekitar 12 VDC dan 5 VDC, meskipun ada sedikit perubahan namun rata-rata Vout catu daya sudah memadai untuk digunakan.

\subsection{Hasil Pengujian dan Analisa Relay}

Tabel 3. Hasil Pengujian Relay

\begin{tabular}{|c|c|c|}
\hline Pengukuran & $\begin{array}{c}\text { Pemakaian Arus } \\
(\mathrm{mA})\end{array}$ & Keterangan \\
\hline \hline 1 & 69.90 & Relay non aktif \\
\hline \hline 2 & 79.89 & Relay non aktif \\
\hline \hline 3 & 79.89 & Relay non aktif \\
\hline \hline 4 & 100.33 & Relay non aktif \\
\hline \hline 5 & 110.21 & Relay non aktif \\
\hline \hline 6 & 133.20 & Relay aktif \\
\hline \hline 8 & 131.15 & Relay aktif \\
\hline \hline 9 & 143.12 & Relay aktif \\
\hline \hline 10 & 141.09 & Relay aktif \\
\hline \hline
\end{tabular}

Dari hasil pengukuran nampak bahwa pada saat relay standby artinya relay tidak aktif pemakaian arusnya sekitar $70 \mathrm{~mA}$ sedangkan pada saat relay aktif 
pemakaian arus meningkat dua kali lipat menjadi $140 \mathrm{~mA}$. Hal ini berarti pemakaian arus oleh relay cukup besar. Hal ini wajar karena relay yang digunakan cukup besar sehingga mampu menangani beban yang besar (5A). Pemakaian relay yang besar otomatis akan meningkatkan pemakaian arusnya.

\subsection{Hasil Pengujian dan Analisa Sensor Infra Merah}

Tabel 4. Hasil Pengujian Sensor Infra Merah Kondisi Tertutup

\begin{tabular}{|c||c|c|}
\hline Infra & $\begin{array}{c}\text { Output infra merah pada saat } \\
\text { tertutup }\end{array}$ & $\begin{array}{c}\text { Output setelah melewati } \\
\text { Schmitt trigger }\end{array}$ \\
\hline \hline 1 & $3,1 \mathrm{~V}$ & $5 \mathrm{~V}$ \\
\hline 2 & $3,2 \mathrm{~V}$ & $5 \mathrm{~V}$ \\
\hline 3 & $3 \mathrm{~V}$ & $5 \mathrm{~V}$ \\
\hline 4 & $3,2 \mathrm{~V}$ & $5 \mathrm{~V}$ \\
\hline 5 & $3,2 \mathrm{~V}$ & $5 \mathrm{~V}$ \\
\hline 6 & $3,3 \mathrm{~V}$ & $5 \mathrm{~V}$ \\
\hline \hline 7 & $3,8 \mathrm{~V}$ & $5 \mathrm{~V}$ \\
\hline \hline 8 & $3,4 \mathrm{~V}$ & $5 \mathrm{~V}$ \\
\hline \hline 9 & $3,5 \mathrm{~V}$ & $5 \mathrm{~V}$ \\
\hline
\end{tabular}

Tabel 5. Hasil Pengujian Sensor Infra Merah Kondisi Terbuka

\begin{tabular}{|c||c|c|}
\hline Infra & $\begin{array}{c}\text { Output infra merah pada saat } \\
\text { tertutup }\end{array}$ & $\begin{array}{c}\text { Output setelah melewati } \\
\text { Schmitt trigger }\end{array}$ \\
\hline 1 & $3,1 \mathrm{~V}$ & $5 \mathrm{~V}$ \\
\hline 2 & $3,2 \mathrm{~V}$ & $5 \mathrm{~V}$ \\
\hline \hline 3 & $3 \mathrm{~V}$ & $5 \mathrm{~V}$ \\
\hline 4 & $3,2 \mathrm{~V}$ & $5 \mathrm{~V}$ \\
\hline 5 & $3,2 \mathrm{~V}$ & $5 \mathrm{~V}$ \\
\hline 6 & $3,3 \mathrm{~V}$ & $5 \mathrm{~V}$ \\
\hline 7 & $3,8 \mathrm{~V}$ & $5 \mathrm{~V}$ \\
\hline 8 & $3,4 \mathrm{~V}$ & $5 \mathrm{~V}$ \\
\hline \hline 9 & $3,5 \mathrm{~V}$ & $5 \mathrm{~V}$ \\
\hline
\end{tabular}

Perancangan Pengaturan Sinyal/Rambu Pada Stasiun.....( Ketut Udy Ariawan) 


\subsection{Hasil Pengujian dan Analisa Fungsional Sistem}

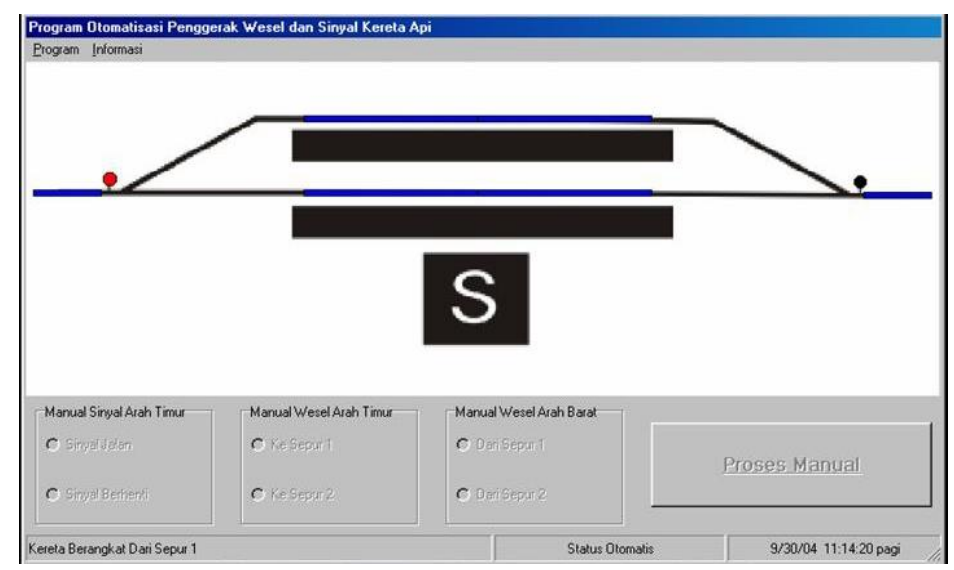

Gambar 5. Tampilan Program Menggunakan Borland Delphi 5.0

Dalam pengujian ini yang dicari bukanlah berapa nilai pengukuran yang akurat melainkan analisis perbandingan relatif beberapa pengujian yang dilakukan untuk mengetahui seberapa jauh faktor sensor dan jaringan berpengaruh terhadap akurasi data. Dengan kata lain yang dibutuhkan adalah perbandingan relatif bukan nilai akurat.

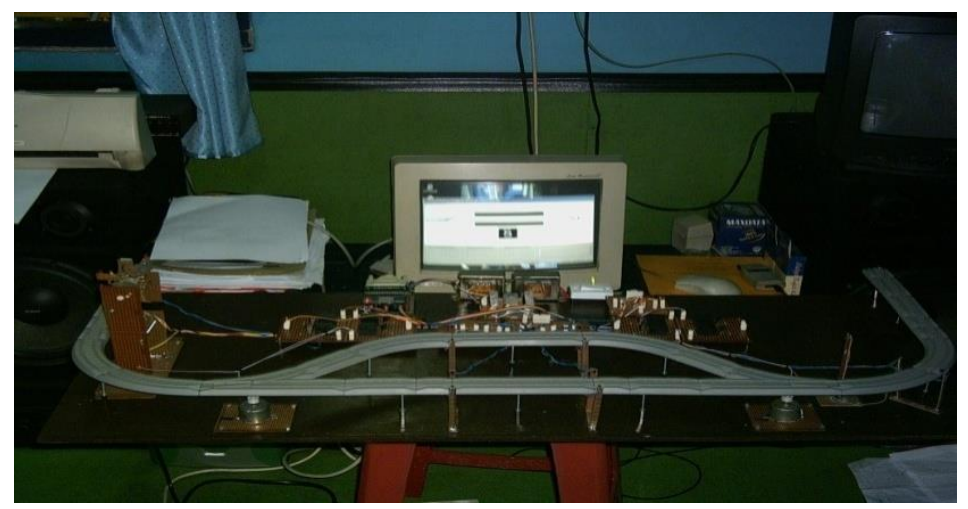

Gambar 6. Skema Rangkaian Keseluruhan

\section{PENUTUP}

Dari hasil pengujian dan analisa yang telah dilakukan dapat dilihat bahwa software dapat digunakan baik secara otomatis maupun manual dengan mengaplikasikan program Borland Delphi 5.0 serta hardware yang digunakan 
bekerja dengan baik sesuai dengan perintah yang diberikan oleh software, sehingga dengan demikian dapat disimpulkan bahwa seluruh sistem yang dirancang bekerja sesuai dengan spesifikasi yang diinginkan, keakuratan sistem cukup bisa diandalkan walaupun tidak sesempurna sesuai dengan kenyataannya mengingat beberapa komponen yang digunakan hanya sebagai simulasi saja, hasil perancangan dari sistem ini hanya bisa digunakan untuk melayani kereta yang satu jalur saja, sistem ini mampu digunakan pada stasiun kereta api berskala kecil yang masih menggunakan teknologi konvensional untuk mengurangi faktor kesalahan manusia (human error).

Untuk dapat lebih menyempurnakan sistem ini dapat ditambahkan rangkaian alarm/buzzer sebagai tanda apabila sistem tidak bekerja sesuai dengan yang diinginkan sehingga tingkat keamanan kereta api bisa lebih terjamin, gunakan sensor khusus yang dapat mendeteksi kereta diantaranya kamera, dimungkinkan untuk dilakukan penelitian lagi supaya sistem dapat menerima pelayanan untuk kereta dua jalur. Bahasa pemrograman untuk aplikasi dapat menggunakan, Pascal, Visual Basic, atau pemrograman lainnya yang lebih canggih. Sistem yang di rancang dapat dikembangkan untuk spesifikasi yang lain dan tidak terbatas pada penggerak wesel dan sinyal saja, tetapi mungkin juga dapat mengenali citra yang sebenarnya.

\section{DAFTAR PUSTAKA}

Alan V. Oppenhem, Alan S. Willsky \& S. Hamid Nawab, 2000, Sinyal \& Sistem. Erlangga, Jakarta.

Cooper \& Wiliam D., 1993, Instrumentasi Elektronik dan Teknik Pengukuran, Edisi Kedua Terjemahan S. Pakpahan, Erlangga, Jakarta.

Dally \& James W., 1984, Instrumentation for Engineering Measurement, Iowa, Iowa University Press.

Endel Uiga, 1995, Optoelectronics, Prenctice-Hall International Inc., Englewood Cliffs, New Jersey Columbus, Ohio. 
Elektuur, 1994, Data Sheet Book 1, Data IC Linear, TTL, dan CMOS, Cetakan ke-2 Terjemahan Wasito S, PT. Elex Media Komputindo, Jakarta.

Hall \& Douglas V, 1992, Microprocessors And Interfacing, Programming And Hardware 2nd Edition, McGrow Hill Inc, Singapore.

Inge \& Martina, Pemrograman Borland Delphi 5.0, PT. Elex Media Computindo, Jakarta.

Jacob Fraden, 1996. Handbook of Modern Sensors (Physics, Design, and Applications) Second Edition, Thermoscan Inc., San Diego, California. 